\title{
Technological innovations in the work environment and the career of the millennium generation
}

\author{
Elza Veloso \\ Faculdade FIA de Administracao e Negocios, Sao Paulo, Brazil \\ Rodrigo Cunha da Silva \\ Universidade Anhembi Morumbi, Sao Paulo, Brazil \\ Leonardo Trevisan \\ Pontifícia Universidade Católica de São Paulo, São Paulo, Brazil, and \\ Joel Dutra \\ Universidade de Sao Paulo, Sao Paulo, Brazil
}

\begin{abstract}
Purpose - The purpose of this paper is to identify the relationship of career anchors with three aspects: the millennials' professional skills, the millennials' awareness of the replacement of jobs with new technologies and the technological stress in the millennials' working environment.

Design/methodology/approach - The responses of 200 questionnaires were analyzed using descriptive and variance analysis techniques.

Findings - Among the three hypotheses raised, two were confirmed, showing that these young people recognize the development of professional skills through new technologies, but are not highly sensitive to the stress associated with technological innovations.

Originality/value - The paper contributes to a recent debate, which emphasizes the impact of the application of new technologies on the nature of study and employment levels.
\end{abstract}

Keywords Technological innovation, Technological stress, Professional skills,

Millennium generation

Paper type Research paper

\section{Introduction}

Current discussions on the topic of "career" are permeated by growing concerns regarding the transformations the work has undergone over time. Such changes are driven by recent technological innovations that increasingly alter the nature of professional activities, technical and routine, as well as intellectual and creativity-dependent (Autor \& Price, 2013; Barley, Bechly, \& Milliken, 2017; Frey \& Osborne, 2013).

(C) Elza Veloso, Rodrigo Cunha da Silva, Leonardo Trevisan and Joel Dutra. Published in Innovation \& Management Review. Published by Emerald Publishing Limited. This article is published under the Creative Commons Attribution (CC BY 4.0) license. Anyone may reproduce, distribute, translate and create derivative works of this article (for both commercial and non-commercial purposes), subject to full attribution to the original publication and authors. The full terms of this license may be seen at http://creativecommons.org/licences/by/4.0/legalcode

Career of the millennium generation

Received 6 June 2019 Revised 28 September 2019

17 January 2020 Accepted 20 January 2020

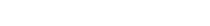


INMR

17,4

Automation overwork, robotics and artificial intelligence, in this order of evolution, defined both the need to associate career with technology and the urgency of analysis, more systematized, of literature on the subject. Among the results of this observation, it is worth noting that one of the most significant social impacts of the advancement of these technologies is on employment levels (CIPD, 2017).

While discussions about career and technology advance from different angles, questions about the work of young people of the millennium generation also remain present (Novella, Repetto, Rabino, \& Rucci, 2018). The importance of studying the career of young Brazilians in their association with technological innovations through career anchors was emphasized by Veloso, Trevisan, Silva, and Dutra (2018). In this work, the potential of the traditional anchor approach (Schein, 1985), which has been used for 40 years, as compared with contemporary career theories, which have been addressed in several current international studies (Barley et al., 2017; Callanan, Perri, \& Tmkowicz, 2017; Guan, Arthur, Khapova, Hall, \& Lord, 2017; Hall, Yip, \& Doiron, 2018).

The use of anchors to understand current technological phenomena is corroborated in international studies (Bravo, Seibert, Kraimer, Wayne, \& Liden, 2015). These authors explain that, despite the possibility that the anchors present outdated assumptions because they were developed in times of more stable employment because they focus on values and internal needs, they continue to be useful for understanding career choices. Thus, as the potential of the career anchor concept is not exhausted, it is pertinent to conduct new research to promote the updating of its use.

In contextual terms, the fact that, in the current scenario, there is a tendency for managerial decisions on the movement of people to be postponed by organizations, generating difficulties in defining professional trajectories and in applying clear criteria for career progression is highlighted. This scenario has generated a high level of stress for individuals, resulting not only from the lack of clarity but also from the precariousness and ambiguity involved in career development, in a context of growing technological innovations and consequent replacement of jobs by machines (Budtz-Jørgensen, Johnsen, \& Sørensen, 2019).

In view of these reflections, the aim of the research presented in this article is to identify the relationship of career anchors with three aspects: the millennials' professional skills, the millennials' awareness of the replacement of jobs with new technologies and the technological stress in the millennials' working environment. To achieve this goal, questionnaires were analyzed and answered by 208 young people (200 of them complete), all final year students in business administration at a private university in the city of São Paulo. It is worth noting that the importance of studying the career of millennials lies in the fact that this group of workers is at the peak of their productive life. According to IBGE, in the year 2015, people between 25 and 49 years old had an occupation rate of $75.4 \%$ (IBGE, 2016).

\section{Theoretical reference}

\subsection{Generation millennium and its relationship with technology}

The "generation" construct demands social comparison, in a defined historical perspective, both in relation to expectations and in relation to the changes and characteristics of each new economic and socio-cultural context, with the formation of some unifying common points, as proposed in the study by Lyons and Kuron (2014). Although the studies of generations accumulate significant quantitative density and have achieved recognized relevance, the delimitations of generational groups are not always consensual. Urick, Hollensbe, and Fairhurst (2017), when researching conceptions regarding generations in the 
labor market, identified well-characterized perceptions about the definition of a generation, which can be understood, first, by the contribution and impact of its members on society or organizations; then, by the individual perception of what a generation is; finally, through the role of a group of people within other generational groups and also including the classic definition of "young" and "old."

To prevent confusion in the delimitation between generations and comparison between different national cultures, Costanza, Darrow, Yost, and Severt (2017) recommend that people born from 1980 to the present day be categorized as millennium generation, with a view to their entry into the labor market from the 2000s. In addition, it is important to remember the scarcity of valid empirical studies to identify a subsequent generation. However, this categorization is not unanimous. In the international context, Hershatter and Epstein $(2010,2016)$ consider that the millennials entered the labor force in 2004. These authors realized that, for the young people of this generation who are graduated at the university level, the incorporation of technology happens as a kind of "sixth sense," as a totally integrated means of their interaction with the world. They also observed that there is, for these people, an expectation of organizational accommodation, according to their previous experiences, that is, the organizations, in a way, have become malleable to accommodate the needs and desires of the millennium generation.

In turn, in the study by Novella et al. (2018), published by the Inter-American Development Bank, carried out between the years 2017 and 2018, research was conducted on work and education in Latin America and the Caribbean in which young people between the ages of 15 and 24 were considered members of the millennials generation. At this point, it is important to note that the survey presented in this article was also conducted in 2017 and 2018, with young people born from 1993 onwards, i.e. with a maximum age of 24 or 25 at the time the questionnaires were applied. Therefore, due to the age approximation with the delimitation of Novella et al. (2018) and the fact that Brazil is framed in this study, the young people researched here were classified as millennium generation.

The study of careers linked to technological innovations has gained significant emphasis in recent years. Brougham and Haar (2017) explained that entrepreneurs and "futurists" suggest that, because of the rapid advances in automation, robotics and decision-making power delegated to algorithms, from the consolidation of the principles of artificial intelligence in all professional scenarios, society lives with the full "fourth industrial revolution." Despite all the differences faced by different degrees of economic development, these authors state that little research has been undertaken to understand the way workers view their work and their careers amid so many potential changes.

It is in this context of profound changes in the relationship between human labor and technologies that Lyons et al. (2015) emphasized the growth of pressures for individuals to become responsible for their own professional and technological development. In terms of generations, these authors reflected on the fact that baby boomers, members of the $\mathrm{X}$ and $\mathrm{Y}$ generations were equally pressured by career changes. However, at the same time, the millennials' generation was the most affected by changes in the labor market, which imposed the acceptance of non-traditional employment contract arrangements (temporary and multiple ties) redefining, in broad terms, the dynamics of traditional careers.

The transition from traditional careers to new work arrangements requires new reflections, especially in relation to the work of new generations, in their orelationship with technology. In this sense, to understand the relationship between young people and technological advances, Veloso et al. (2018) used the division between traditional and non-traditional theories, proposed by Arthur, Inkson, and Pringle (1999). Traditional theories, created to consider stable employment scenarios, were represented by career anchors. Non-traditional theories, created to
Career of the millennium generation

381 
INMR

17,4

consider people working less dependently on firms, were represented by the profile of intelligent careers (Veloso et al., 2018). These two models are explained below.

\subsection{Career anchors}

With the purpose of understanding the evolution of careers and the values present in professional activity, the "career anchors" were created by Schein $(1985,1990)$ and highlight the professional inclination, which has deep meaning for the person, representing his selfimage. From this study and some of its developments, the following classification was defined:

- Technical/functional competence (TF): It represents professional achievement through the confrontation of challenges in technical areas, causing the person to avoid managerial positions when they require removal from their specialty.

- General management competence (GM): It represents the professional achievement related to the responsibility for results and the identification of the work itself with the success of the organization.

- Autonomy/independence (AI): It represents the intolerance to rules established by other people and the organization, the rejection of forms of control and the search for functions that allow flexibility.

- Security/stability (SS): It represents a greater concern with job security and the feeling of tranquility for professional stability than with the content of the job.

- Entrepreneurial creativity (EC): It represents the search for the creation of the organization itself, of products or services, the responsibility for risks and the constant search for future opportunities.

- Service/dedication to a cause (SD): Represents the search for the accomplishment of something useful that involves, for example, helping and improving harmony between people and solving environmental problems.

- Pure challenge (PC): It represents the search for solutions to problems that seem insoluble, the transposition of difficult obstacles and the overcoming of opponents.

- Lifestyle (LS): It represents the search for balance between personal, professional and family needs and sufficient flexibility to integrate all elements of life.

In the vision of the anchors, the inclination of the professional is highly significant for the individual, because it rescues the notion of comfort and adjustment that make the person seek to return to them when acting in disagreement with their goals and attitudes. The tendency, according to Schein (1996a), is that the person does not abandon his/her anchor, even in crisis situations. In the Brazilian context, Silva, Trevisan, Veloso, and Dutra (2016) used career anchors to understand the values of generation $\mathrm{Y}$ and identified the anchor Lifestyle as predominant among the young people analyzed.

Arnold (2001) considers career anchors as a way of analyzing career success and explains that although there is no vast literature on this concept, which became prominent in the 20th century, Schein (1996b) discussed how anchors can also be applied to 21st-century careers. As an example, Arnold (2001) elucidates that people who manifest the predominance of the anchor Security/Stability may have more vulnerable careers; however, those who manifest the anchor Technical/Functional Competence know that specialists will always be needed. 


\subsection{Anchors and smart careers to understanding the millennium generation}

However, Arnold (2001) points out that keeping oneself updated is an essential factor for survival in new technological scenarios, regardless of the prevailing anchor. It is an inherent need of professional evolution that everyone keeps themselves always updated, because all people, regardless of their anchors, must recognize the inevitability of changes, whether in the nature of the knowledge or in the profile of the skills required in professional exercise. In this sense, the intelligent career model configured as a way to understand the need for constant updating emerges (Arnold, 2001). This career format has built a model based on skills suitable for a world of work typical of the past decade of the 20th century, a time when jobs became unstable and companies went through downsizing waves (Gunz, Evans, \& Jalland, 2000).

In the full consolidation of these changes, Arthur, Claman, and DeFillipi (1995) have already presented the vision that, to operate in an unstable labor market, people need to develop three types of professional skills, which are transferable between organizations and not subordinated to any employer:

(1) Knowing why: It represents individual identity and motivation, personal significance and identification with the work.

(2) Knowing how: It represents the individual skills and specialties relevant to the job.

(3) Knowing whom: It represents the interpersonal relations and networks important for the work.

These skills are obtained through education, work and life experience and are considered a "career capital," which may acquire or lose value, depending on the investment made in each one (Arthur et al., 1999). Beiji, Shirmohammadi, and Arthur (2018) found links and relationships between these three skills and explained the importance of examining these links further, rather than studying these three components separately. Thus, an important aspect of intelligent career theory, as its emergence has been the interrelationship between the three skills. However, these relationships are rarely studied. In Brazil, although with a small variation in the delimitation of generations, Veloso, Silva, and Dutra (2012) and Veloso, Dutra, and Nakata (2016) used the skills of intelligent careers to understanding generational differences in their career perceptions in the organizational context. In these two studies, among other results, it was found that knowing-why perceptions stand out favorably from the other two skills in the three generations.

The study of intelligent careers associated with career anchors and technology was conducted by Veloso et al. (2018). These authors stated that only traditional theories, represented by anchors, are not sufficient to explain the impact of new technologies in the labor market. On the other hand, non-traditional theories, represented by intelligent careers, can help people, especially the millennium generation, to deal with technological innovations. Thus, for the formulation of the first hypothesis, it was considered that career anchors and professional skills have mutually complementary potential in the study of phenomena involving technological innovations and the career of young workers:

H1. There is a difference in the development of professional skills according to the main career anchor.

\subsection{Technological innovations in the work environment}

The study mentioned in the introduction of this article (ICPD, 2017), carried out by the Chartered Institute of Personnel and Development, had among its focuses of analysis the 
INMR

17,4

understanding of the impacts of automation, robotics and artificial intelligence on professions and society. The results showed that, while some authors predict large-scale job losses due to the automation of non-routine jobs, others do not believe that this will happen, because the possibility of replacing human work with that of machines does not characterize a new phenomenon in human evolution (CIPD, 2017). Moreover, considering the study of leadership in the organizational context, it is possible to observe, even from a two-decade perspective, that both technological changes and the dynamics of globalization itself have influenced the work of people and organizations in a diffuse but lasting way (Hartog \& Koopman, 2001). In administrative and service work, an important impact is a growing need for both workers and consumers to communicate and interact with the new technologies (CIPD, 2017).

The nature of work has changed due to technological innovations, causing organizations to change as the way they work changes (Barley et al., 2017). At the same time, these changes in tasks cause transformations in the very organizations. These reflections express the importance of studying technological innovations, especially in their associations with the career (Barley et al., 2017). The CIPD (2017) report gathered empirical evidence from several studies (Pinkwart, 2016; Sutton, Holt, \& Arnold, 2016) that present the way in which changes in the nature of work happen through technology. According to these reflections, the nature of work changes "through automation and computerization of routine tasks" and "through the involvement of greater interaction and the use of robots and artificial intelligence systems which increasingly facilitate various aspects of people's work activities" (CIPD, 2017, p. 13).

Surveys point out that people will be replaced by machines. Frey and Osborne (2013) calculated that $47 \%$ of human occupations could be automated within a decade. The speed of the transformations that would cause human labor to be replaced by machines was calculated based on the analysis of the standards required by each of the 903 occupations listed in the US Department of Labor. The opposition of these tasks with the advances achieved by the cumulative data logic of big data led to the conclusion that 702 of these 903 occupations could be standardized and automated; thus they were capable of being made by machines. While another important study by Autor and Price (2013) concluded that only routine tasks that could be replaced by computerized standards could be performed by machines, the study by Frey and Osborne (2013) showed that not even jobs that demanded a flexibility of analysis, problem-solving and interaction would be protected. Despite the evidence found by these authors, workers in Brazil, in general, are still not concerned about the fact that technological innovations may cause the replacement of their jobs by machines (Trevisan, Veloso, Silva, \& Dutra, 2016; Veloso et al., 2018).

In this scenario, it is important to understand how much people's role has changed, especially in certain service settings. This reflection is of vital importance, both for the management of private companies and for the sphere of public policy decisions and must consider the need to prepare the future of the workforce. Innovative professionals are able to deal with conflicts that result from failures in technology or the inability of internal and external clients to deal with certain connections. These people are able to harmonize the interdependencies between different partners in the form of a network and differentiate their careers by exhibiting authentic behaviors in the construction of a kind of "personal brand" (Larivière, Bowen, Andreassen, Kunz, Sirianni, Voss, Wünderlich, \& De Keyser, 2017). With this, it can be assumed that different career attitudes, represented by the career anchor, imply different consciences as to the possibility of replacing jobs with new technologies. Therefore: 
H2. There is a difference in awareness about replacing jobs with new technologies, according to the main career anchor.

Career of the millennium generation

\subsection{Technological stress}

While technology can improve the pace of work, it can also be difficult to deal with. ICPD research (2017) emphasizes an experiment by Dang and Tapus (2015) on young people's attitudes toward the use of robot assistance, whose results show that, although people want to use this assistance, its use has not resulted in improved performance at work. In parallel, the study by Nomura, Kanda, Yamada, and Suzuki (2011) was cited, concluding that people with strong anxiety symptoms were worsening, with dependence on certain robot behaviors.

Hart and Cooper (2001) argue that the growth of organizational stress is a global problem. Changes in the nature of work lead to concerns about people's well-being and health, who are distressed about their possible loss of connectivity, which can lead to less secure jobs such as part-time work and short-term hiring. According to these authors, in many organizations, rapid technological changes, associated with collections for greater efficiency, competitiveness and improved customer service put people under strong pressure, creating types of work organizations that produce high levels of organizational stress.

In Brazil, Trevisan et al. (2016), stated that it is not possible to directly associate the increasing use of technology with stress in the work environment. However, these authors emphasize the fact that it was possible to identify that signs of "electronic competition" with human tasks generate stress, as demonstrated in research with young university students. In this study, there is the statement that stress in the work environment "is born with the perception that, without relevant skills, one does not live with new technologies" and that stress advances, with intensity, "to the extent that workers identify that the process of assimilation of new skills is continuous and incessant" (Trevisan et al., 2016, p. 68).

Budtz-Jørgensen et al. (2019) explained that the functional limits of enterprises are often associated with people skills. Professional specialization can serve to enable or restrict career development. These authors emphasized that, in the past, when jobs were more stable, career progression was more easily associated with a specific set of skills. However, in the current technological context, there is a constant need for reinvention and acquisition of new professional skills, requiring an increasing ability to play a variety of roles within the organization. The observation of this reasoning allows the assumption that, depending on personal attitudes, represented by career anchors, technological stress may present different intensities, according to the fourth hypothesis of this study:

H3. There is a difference in technological stress according to the main career anchor.

\section{Methodology}

A survey was conducted with 208 students at a private institution of higher education in the city of São Paulo, from the past year of the administration course, with 107 students in 2017 and 101 in 2018. The questionnaire was applied after teachers' permission, in class, at predetermined periods. However, only the students who answered the questionnaire in full were considered for this research; therefore, the answers of eight participants were disregarded, totaling 200 respondents, born from 1993 onwards, as explained in the introduction to this article. 
INMR

17,4

386

\subsection{Preparation of the research instrument}

The research instrument was composed of two parts, the first of which is made up of the questions contained in the inventory of career anchors, prepared by Schein (1990). In the second part, 15 statements were presented with the purpose of ascertaining perceptions regarding the incorporation of technological innovations in the work environment, including professional skills (intelligent careers); the stress associated with technological innovations (technological stress) and the awareness regarding the possibility of replacing jobs with technology.

Table 1 shows the authors who justified the preparation of the second part of the questionnaire.

In addition to the conceptual basis, all the statements in the questionnaire were prepared on the Likert type numerical scale. This choice is due to its use in the field of applied social sciences and to the fact that it shows no signs of damage or bias to the general validity of the results. In international research on generations, the Likert scale is conventionally accepted in the measurement of perceptions (Costanza et al., 2017). Then, the statements had their scores standardized for regression analysis, that is, the values were expressed in terms of their difference from the mean, divided by the standard deviation, which allows statistical analysis together for modeling.

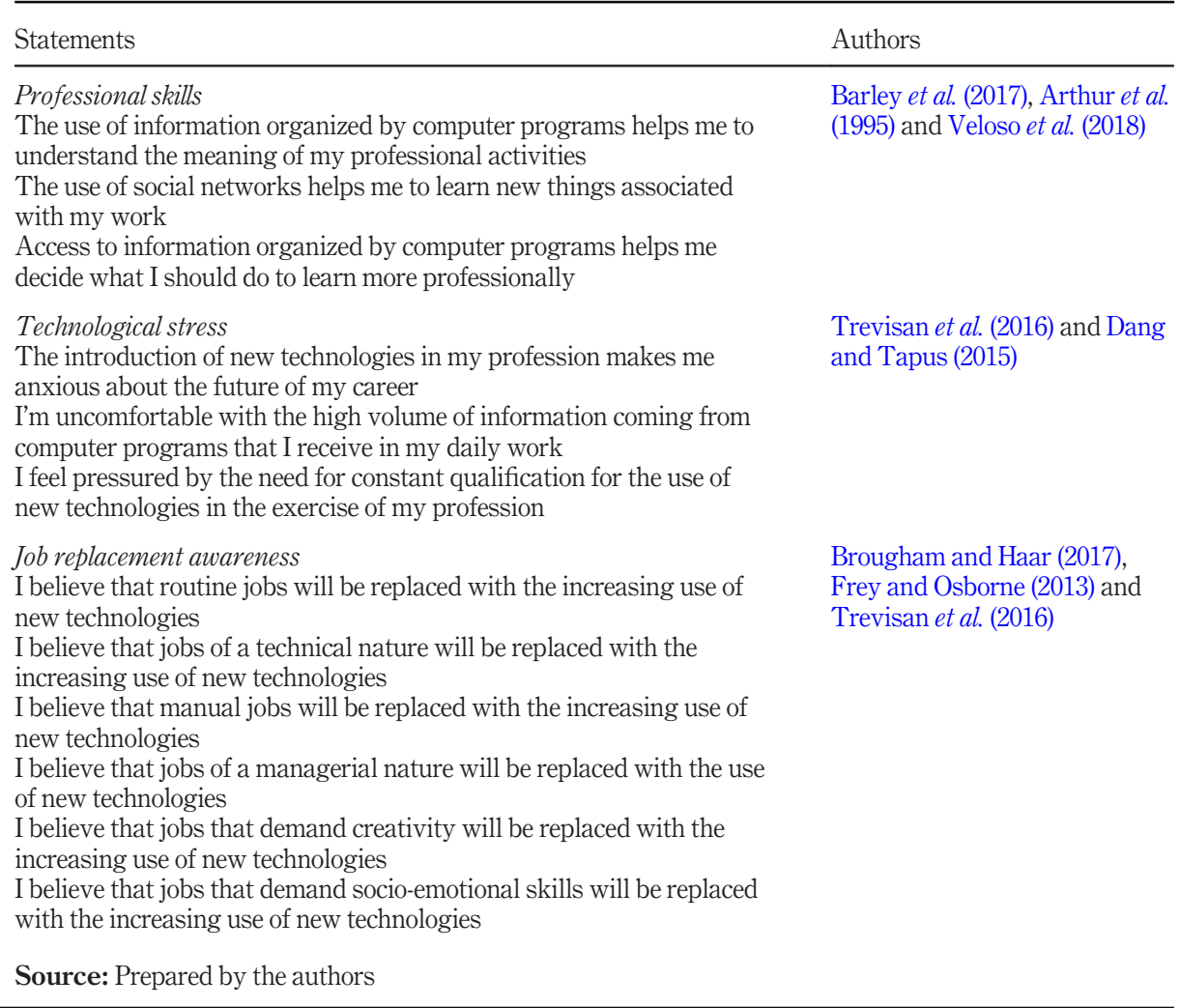

Table 1.

Theoretical background to the second part of the questionnaire 


\subsection{Technical procedures for analyzing the results}

The initial procedure was to perform descriptive analyzes of the means and standard deviation for all the questionnaire statements. Then, Kolmogorov-Smirnov indexes were calculated to check univariate normality to use the analysis of variance (ANOVA) technique. The K-S test has as $H O$ that the distribution of the variable is normal, which was verified in the variables under analysis. Therefore, the ANOVA was performed with the Scheffe post hoc test.

ANOVA aims to measure differences for two or more metric variables, seeking to verify

Career of the millennium generation the existence of differences in respondents' perceptions. The main career anchor of the respondents was considered as an independent variable, i.e. the anchor with the highest average among the eight. As a dependent variable, the average scores of the statements, presented in Table 1, on the perception of the impact of technological innovations on the work environment were considered.

\section{Analysis of results}

The mean age of the respondents is 23 years, with a standard deviation of 3.9 , therefore, classified in the period of the birth of the millennium generation considered in this study and justified in the introduction of the work. The average time worked in the company is 1.8 years, with a standard deviation of 1.4 . Approximately $70 \%$ of respondents are male and $87 \%$ work. Among the respondents working, $44.5 \%$ are from the service sector, $25.5 \%$ from industry, $18 \%$ from commerce and $12 \%$ from other sectors (public or third sector). The positions they hold are distributed in $27.5 \%$ administrative positions, $27 \%$ finance and controlling, $17.5 \%$ production and supplies, $14.5 \%$ marketing and sales, $9 \%$ human resources and $4.5 \%$ information systems.

Table 2 are the means and standard deviations of the respondents' career anchor scores.

In general, the anchor with the highest average was lifestyle (4.69) and the lowest was general management (3.59). The standard deviations present similar results in the anchors. In turn, the mean values and standard deviations of the assertions of the second part of the questionnaire are presented in detail in Table 3.

The category with the highest average was professional skills and the lowest was the one dealing with technological stress. Thus, apparently, respondents tend to agree that they develop intelligent careers with the use of technology and disagree with the incidence of stress resulting from the context of technological innovation.

The assertion with the highest average was "I believe that routine jobs will be replaced with the increasing use of new technologies" and the lowest was "I believe that jobs that demand creativity will be replaced with the increasing use of new technologies."

\begin{tabular}{lcc}
\hline Anchor & M & DP \\
\hline Technical-functional (TF) & 4.17 & 0.97 \\
General management (GM) & 3.89 & 1.16 \\
Autonomy and independence (AI) & 4.31 & 1.28 \\
Security and stability (SS) & 4.00 & 1.22 \\
Entrepreneurial creativity (EC) & 3.90 & 1.53 \\
Service and dedication to a cause (SD) & 4.05 & 1.34 \\
Pure challenge (PC) & 4.26 & 1.14 \\
Lifestyle (LS) & 4.69 & 1.33
\end{tabular}

Source: Prepared by the authors

Table 2. Averages and standard deviation of career anchors 


\begin{tabular}{|c|c|c|c|c|}
\hline \multirow{4}{*}{$\begin{array}{l}\text { INMR } \\
17,4\end{array}$} & & & & \\
\hline & \multicolumn{2}{|l|}{ Code } & M & $\mathrm{DP}$ \\
\hline & \multicolumn{2}{|c|}{ Professional skills } & 3.56 & 0.70 \\
\hline & why & $\begin{array}{l}\text { The use of information organized by computer programs helps me to } \\
\text { understand the meaning of my professional activities }\end{array}$ & 3.74 & 1.01 \\
\hline \multirow{2}{*}{388} & whom & $\begin{array}{l}\text { The use of social networks helps me to learn new things associated with } \\
\text { my work }\end{array}$ & 3.22 & 1.17 \\
\hline & how & Access to information organized by computer programs helps me decide & 3.72 & 0.97 \\
\hline \multirow{12}{*}{$\begin{array}{l}\text { Table } 3 \text {. } \\
\text { Averages and } \\
\text { standard deviations } \\
\text { of the assertions } \\
\text { about the } \\
\text { incorporation of } \\
\text { technological } \\
\text { innovations in the } \\
\text { work environment }\end{array}$} & \multicolumn{2}{|l|}{ Stress } & 2.43 & 0.96 \\
\hline & estr1 & $\begin{array}{l}\text { The introduction of new technologies in my profession makes me anxious } \\
\text { about the future of my career }\end{array}$ & 2.20 & 1.21 \\
\hline & estr2 & $\begin{array}{l}\text { I'm uncomfortable with the high volume of information coming from } \\
\text { computer programs that I receive in my daily work }\end{array}$ & 2.16 & 1.13 \\
\hline & estr3 & $\begin{array}{l}\text { I feel pressured by the need for constant qualification for the use of new } \\
\text { technologies in the exercise of my profession }\end{array}$ & 2.93 & 1.38 \\
\hline & \multicolumn{2}{|c|}{ Awareness of job substitution possibilities } & 2.89 & 1.10 \\
\hline & consc1 & $\begin{array}{l}\text { I believe that routine jobs will be replaced with the increasing use of new } \\
\text { technologies }\end{array}$ & 3.87 & 1.01 \\
\hline & consc2 & $\begin{array}{l}\text { I believe that jobs that are technical in nature will be replaced with the } \\
\text { increasing use of new technologies }\end{array}$ & 3.31 & 1.02 \\
\hline & consc3 & $\begin{array}{l}\text { I believe that manual jobs will be replaced with the increasing use of new } \\
\text { technologies }\end{array}$ & 4.43 & 1.11 \\
\hline & consc4 & $\begin{array}{l}\text { I believe that jobs of a managerial nature will be replaced with the use of } \\
\text { new technologies }\end{array}$ & 2.16 & 1.07 \\
\hline & consc5 & $\begin{array}{l}\text { I believe that jobs that demand creativity will be replaced with the } \\
\text { increasing use of new technologies }\end{array}$ & 1.76 & 1.05 \\
\hline & consc6 & $\begin{array}{l}\text { I believe that jobs that demand socio-emotional skills will be replaced with } \\
\text { the increasing use of new technologies }\end{array}$ & 1.81 & 1.14 \\
\hline & \multicolumn{4}{|c|}{ Source: Prepared by the authors } \\
\hline
\end{tabular}

To compare the impact of career anchors on the mean differences in the survey constructs, the analysis of variance was performed, with subsequent analysis by the Scheffe post hoc test, considering the general means of the survey constructs.

After computing the Kolmogorov-Smirnov test $(p>0.01)$ and homogeneity of variances by the Levene statistics $(\phi>0.05)$, the normality of the three dependent variables regarding the incorporation of technological innovations in the work environment was verified, allowing the parametric test to analyze the differences in means.

Thus, the constructs that presented significant mean differences were professional skills $(F=2.47 p<0.05)$ and awareness $(F=2.20 p<0.05)$. However, there were no significant differences in stress construction $(F=0.61 p<0.05)$. Therefore, $H 1$ and $H 2$ were confirmed and $H 3$ was rejected.

With the help of Table 4, it was found by the Scheffe's post hoc that the anchor lifestyle (EV-3.89) presented the highest average and the anchor service and dedication to a cause (SD- 3.34) presented the lowest average in professional skills development.

$H 2$ was confirmed, as the anchor lifestyle (EV-3.94) presented the highest average and the anchor safety and stability (SE- 2.55) had the lowest average in terms of awareness of the possibility of job substitution by technology. As mentioned above, $H 3$ was rejected because no significant difference was found in technological stress in the work environment, considering the eight career anchors. 


\begin{tabular}{|c|c|c|c|c|}
\hline Anchors $\times$ professional skills & $n$ & Mean & DP & \multirow{2}{*}{$\begin{array}{l}\text { Career of the } \\
\text { millennium } \\
\text { generation }\end{array}$} \\
\hline \multicolumn{4}{|l|}{ Professional skills } & \\
\hline TF & 24 & 3.44 & 0.79 & \\
\hline GG & 30 & 3.42 & 0.61 & \\
\hline $\mathrm{AI}$ & 41 & 3.72 & 0.67 & \\
\hline SE & 17 & 3.60 & 0.55 & \\
\hline $\mathrm{CE}$ & 24 & 3.55 & 0.79 & 389 \\
\hline SD & 29 & 3.34 & 0.69 & \\
\hline DP & 22 & 3.60 & 0.68 & \\
\hline $\mathrm{EV}$ & 13 & 3.89 & 0.62 & \\
\hline Total & 200 & 3.55 & 0.69 & \\
\hline \multicolumn{5}{|l|}{ Stress } \\
\hline $\mathrm{TF}$ & 24 & 2.23 & 0.94 & \\
\hline GG & 30 & 2.44 & 0.87 & \\
\hline AI & 41 & 2.41 & 1.17 & \\
\hline SE & 17 & 2.39 & 0.74 & \\
\hline $\mathrm{CE}$ & 24 & 2.29 & 1.03 & \\
\hline SD & 29 & 2.56 & 0.80 & \\
\hline DP & 22 & 2.37 & 0.84 & \\
\hline EV & 13 & 2.82 & 1.07 & \\
\hline Total & 200 & 2.42 & 0.95 & \\
\hline \multicolumn{5}{|l|}{ Awareness } \\
\hline $\mathrm{TF}$ & 24 & 2.77 & 0.60 & Table 4. \\
\hline GG & 30 & 2.82 & 0.57 & Differences in means \\
\hline AI & 41 & 2.92 & 0.69 & and standard \\
\hline SE & 17 & 2.55 & 0.45 & deviations when \\
\hline $\mathrm{CE}$ & 24 & 2.84 & 0.56 & associating career \\
\hline SD & 29 & 2.90 & 0.39 & assolanch tors and \\
\hline DP & 22 & 2.67 & 0.68 & $\begin{array}{l}\text { anchors and } \\
\text { nercentions of }\end{array}$ \\
\hline EV & 13 & 3.94 & 3.67 & perceptions of the \\
\hline Total & 200 & 2.88 & 1.10 & incorporation of new \\
\hline \multicolumn{4}{|l|}{ Source: Prepared by the authors } & work environment \\
\hline
\end{tabular}

\section{Discussions and analysis}

Over the years, studies with a similar audience to the one discussed in this article have pointed the anchor lifestyle as predominant and consolidated among young students of administration (Gomes, Trevisan, Silva \& Veloso, 2013; Silva et al., 2016; Trevisan et al., 2016; Veloso, Silva, Gomes, Trevisan, \& Dutra, 2014; Veloso et al., 2018). However, the lower incidence of the anchor General Management among these youngsters is recent and was pointed out by Silva et al. (2016) and Veloso et al. (2018).

A smaller identification with the anchor general management may mean that even administrators currently identify with transient leadership and more flexible work, less controlled by organizations. This position can be explained by one of the scenarios pointed out by Hartog and Koopman (2001) in which, due to technological advances, the role of leadership is reduced and can present itself as a virtual leadership ("tele-leadership"). In this case, according to these authors, the group interacts and practices self-management and its members are held responsible for the results of the joint work, sharing values and increasing mutual commitment. These reflections allow us to infer that the lower incidence of this anchor may be associated with the current trend of "self-management," dispensing with the view that the results of people's work depend on the performance of managers. 
INMR

17,4

390

It is important to emphasize the categories with the highest average (professional skills) and the lowest average (stress) in the perception of young millennials. This result can be interpreted from reflections on the very characteristics of the millennium generation, which is considered "digital native." Thus, the observation of Hershatter and Epstein (2010) that the most essential "unifying point" of this generation is the continuous and inevitable exposure to a digital world. This exposure is especially consolidated in the process of entering the world of work, so that the incorporation of technological innovations, as they are natural for these young people, do not generate stress, but rather boost the development of skills.

Regarding the assertions proposed in the second part of the questionnaire, the one with the highest average refers to the belief that routine jobs will be replaced because of technological innovations. The lowest refers to the perception that jobs that demand creativity will be replaced by new technologies. These results are consistent with the findings of Autor and Price (2013) that only routine tasks could be performed by machines. At the same time, the millennials have not yet incorporated the awareness associated with the study by Frey and Osborne (2013) that even jobs that demand non-routine and creative tasks, with the flexibility of analysis and interaction, may be replaced by machines in the coming years.

As for the analysis of the hypotheses, $H 1$ has been confirmed, as the anchor lifestyle showed the highest average in its association with intelligent career skills. The anchor service and dedication to a cause, in turn, presented the lowest average in the same association. Observing this result, it is possible to infer that people who manifest the lifestyle anchor tend to take advantage of technology for the development of professional skills, apparently, in a way not very dependent on organizations. However, people in the anchor service and dedication to a cause perceive less the role of technology in the development of their career and have shown to be more dependent on specific scenarios, inside or outside organizations, for the development of their skills.

Because the individuals researched are students, they all live a period of intense acquisition of new skills, through the observation of reference models (Bagdadli \& Gianecchini, 2019). At the same time, innovations take place in the management area. For example, with the use of artificial intelligence, the demand for new competencies can be more or less adherent to the individual career needs of the respondents. Therefore, career anchors support the possibility of holding discussions about these differences among people.

The confirmation of $H 2$ shows that the millennials that manifest the anchor safety and stability tend to have less awareness about replacing people with machines in the work environment. At the other extreme, respondents who manifested the anchor lifestyle tend to have their awareness increased regarding the transformations in work caused by technological innovations. This result shows that people who value reconciliation between personal and professional life, because they need to organize their careers less dependent on organizations, probably see a more changing labor market, more subject to constant change. However, those who value their professional security expect to have more stable jobs and, because of this, tend not to perceive threats to the type of career they want to build.

At this point, it is worth reflecting that the professionals who guide their career decisions toward stability are subject to the illusion that the least professional turbulence will be perpetuated, but the very organizations in which they work usually need to reinvent themselves to remain in their market. Moreover, the notion of being competent in a certain function may not sustain the professional's career, as the function itself may be in transformation, which refers to the need for people to constantly reinvent their careers (Budtz-Jørgensen et al., 2019). The results found in the analysis of the research presented in this article corroborate the statement by Larivière et al. (2017) that professionals with more 
flexible characteristics are more aware of the technological changes that influence their work.

$H 3$ was rejected because there was no significant difference between the anchors in the perception of technological stress. Regardless of the career inclination, all are subject to the same level of stress and it is not possible to attribute to the variations between the anchors the feeling that technological innovations may cause (or not cause) certain professional anxieties. The analysis allows association with the reasoning of Budtz-Jørgensen et al. (2019) in which, due to the business inability to manage careers in ambiguous and uncertain scenarios, high stress has fallen on employees who need to act in environments where occupational identities are diffuse and the notion of which career path to follow depends on an orientation given by personal values.

\section{Final considerations}

The reading of the results presented in this article allowed the analysis of the career of the young people of the millennium generation, by means of their anchors, in a way associated with technological innovations. The reflections undertaken contribute to a recent debate, which emphasizes the impact of new technologies on the nature of work and employment levels (Barley et al., 2017), but takes little account of the consequences of technological changes on individual perceptions of the future of work (Brougham \& Haar, 2017).

In the study of the anchors, the fact that Schein (1996b), at the end of the past century, foresaw the importance of the study of the career anchors for the world of work that would present itself in the 21st century stands out. This author indicated the possibility that people framed in the anchor security and stability could have more difficulties in adapting to the world of work. Schein's observation can be represented by the fact that the youngsters of this anchor see less of a risk of having their jobs replaced by machines than the individuals of the other anchors, practically ignoring the observations of Frey and Osborne (2013).

Further on, in Brazil, Veloso et al. (2014) pointed out, through career anchors, the fact that young people's views of their professional life may change as the economic scenario and the social moment in which the career is inserted are changed. The decline in the manifestation of the general management anchor, exposed among the results of the research presented in this article, may indicate the veracity of this observation.

As for the contributions of this study, it is important to remember that the application of anchors associated with the vision of young administrators on technology is consistent with the perception of Arnold (2001). This author highlights the relevance of this instrument because it represents a stable point from which a person would not wish to depart. Arnold suggests that anchors are useful in helping both individuals and organizations to define what they want and the problems that may arise to achieve their goals. In practical terms, Costa, Rocha and Silva (2018) state that in Brazil public policies are needed not only for the development of technical skills but also of socio-emotional skills so that young millennials can succeed in entering the job market. This article seeks to contribute with discussions consistent with this need.

The research has its limitation in combining two instruments that have different purposes. However, this combination allows renewing the use of career anchors when approaching an audience that has a "digital identity," confirmed by the low perception of stress caused by the incorporation of new technologies.

As for future research, it is also important to consider the need for continuous research on the evolution of the profiles of the people in each of the career anchors. This action causes the revitalization of the constructions proposed by Schein, in a manner consistent with the need for studies on technological advances that should permeate the discussions on business, work and career management.
Career of the millennium generation 
INMR

17,4

\section{References}

Arnold, J. (2001). Careers and career management. In N. Anderson, D. S. Ones, H. K. Sinangil and C. Viswesvaram (Eds.), Handbook of industrial, work and organizational psychology. Volume 2: Organizational psychology (pp. 115-132). London, United Kingdom: Sage Publications.

Arthur, M.B., Claman, P.H. and DeFillipi, R. (1995). Intelligent enterprise, intelligent careers. Academy of Management Executive, 9(4), 7-20. https://doi.org/10.5465/ame.1995.9512032185

Arthur, M.B., Inkson, K. and Pringle, J.K. (1999). The new careers: Individual action and economic change, London, United Kingdom: Sage Publications.

Autor, D.H. and Price, B. (2013). The changing Ttsk composition of the US labor market, an update of Autor, Levy, and Murnane (2003). MIT Paper, June 21, Retrieved from http://economics.mit. edu/les/9758 (Acesso em 09/03/2019).

Bagdadli, S. and Gianecchini, M. (2019). Organizational career management practices and objective career success: A systematic review and framework. Human Resource Management Review, 29(3), 353-370. doi: https://doi.org/10.1016/j.hrmr.2018.08.001

Barley, S.R., Bechly, A.B. and Milliken, F.J. (2017). The changing nature of work lives in the 21st century. Academy of Management Discoveries, 3(2), 111-115. https://doi.org/10.5465/ amd.2017.0034

Beiji, M., Shirmohammadi, M. and Arthur, M.B. (2018). Intelligent career success: The case of distinguished academics. Journal of Vocational Behavior, 107, 261-275. https://doi.org/10.1016/ j.jvb.2018.05.007

Bravo, J., Seibert, S.E., Kraimer, M.L., Wayne, S.J. and Liden, R.C. (2015). Measuring orientations in the era of the boudaryless career. Journal of Career Assessment, 25(3), 1-24. https://doi.org/10.1177/ 1069072715616107

Brougham, D. and Haar, J. (2017). Employee assessment of their technological redundancy. Labour and Industry: a Journal of the Social and Economic Relations of Work, 27(3), 213-231. https://doi.org/ 10.1080/10301763.2017.1369718

Budtz-Jørgensen, J., Johnsen, C. G. and Sørensen, B. M. (2019). Against boundarylessness: The liminal career of the flexible employee. Organization, 26(6), 1-19. https://doi.org/10.1177/1350508418821005

Callanan, G. A., Perri, D. F. and Tmkowicz, S. M. (2017). Career management in uncertain times: Challenges and opportunities. The Career Development Quarterly, 65(4), 353-365. https://doi. org/10.1002/cdq.12113

CIPD. (2017). Impact of artificial intelligence, robotics and automation technologies on work. Rapid Evidence Review. December, 2017. Retrieved from www.cipd.co.uk/knowledge/work/technology/ artificial-intelligence-workplace-impact (Acesso em 06/03/2019).

Costanza, D. P., Darrow, J. B., Yost, A. B. and Severt, J. B. (2017). A review of analytical methods used to study generational differences: Strengths and limitations. Work, Aging and Retirement, 3(2), 149-165. doi: https://doi.org/10.1093/workar/wax002.

Dang, T. H. H. and Tapus, A. (2015). Stress game: The role of motivational robotic assistance in reducing user's task stress. International Journal of Social Robotics, 7(2), 227-240. doi: https://doi. org/10.1007/s12369-014-0256-9

Frey, C. B. and Osborne, M. A. (2013). The future of employment: How susceptible are jobs to computadorisation? Programme on the Impacts of Future Technology Paper, Oxford University Engineering Sciences Department and the Oxford Martin, September 17, Retrieved from www. oxfordmartin.ox.ac.uk/downloads/academic/The_Future_of_Employment.pdf (Acesso em 08/ 03/2019).

Gomes, D. F. N., Trevisan, L. N., Silva, R. C. and Veloso, E. F. R. (2013). Contribuição das âncoras de carreira Para entender diferenças e similaridades de gênero e profissão na geração Y, revista de ciências humanas. Revista de Ciências Humanas, 47(1), 152-171. https://doi.org/10.5007/21784582.2013v47n1p152 
Guan, Y., Arthur, M. B., Khapova, N. K., Hall, R. J. and Lord, R. G. (2017). Career boundarylessness and career success: A review, integration and guide to future research. Journal of Vocational Behavior, 110. https://doi.org/10.1016/j.jvb.2018.05.013

Gunz, H., Evans, M. and Jalland, M. (2000). Career boundaries in a "boundaryless" world. In M. A. Peirpel, M. B. Arthur, R. Gofee and R. T. Morris, (Eds.), Career frontiers: New conceptions of working lives, Oxford, United Kingdom: Oxford University Press.

Hall, D. T., Yip, J. and Doiron, K. (2018). Protean career at work: Self-direction and values orientation in psychological success. Annual Review of Organizational Psychology and Organizational Behavior, 5(1), 1-6. https://doi.org/10.1146/annurev-orgpsych-032117-104631

Hart, P. M. and Cooper, C. L. (2001). Occupational stress: Toward a more integrate framework. In N. Anderson, D. S. Ones, H. K. Sinangil and C. Viswesvaram, (Eds.), Handbook of industrial, work and organizational psychology. Volume 2: Organizational psychology (pp. 93-114). London, United Kingdom: Sage Publications.

Hartog, D. N. D. and Koopman, P. L. (2001). Leadership in organization. In N. Anderson, D. S. Ones, H. K. Sinangil and C. Viswesvaram, (Eds.), Handbook of industrial, work and organizational psychology. Volume 2: Organizational psychology (pp. 166-187). London, United Kingdom: Sage Publications.

Hershatter, A. and Epstein, M. (2010). Millennials and the world of work: An organization and management perspective. Journal of Business and Psychology, 25(2), 211-223. doi: https://doi. org/10.1007/s10869-010-9160-y

Hershatter, A. and Epstein, M. (2016). Millennials and the world of work: An organization and management perspective. In P. S. Herzog (Ed.), The sociology of emerging adulthood: Studying youth context of public issues (pp. 201-224). San Diego, CA: Cognella Academic Publishing.

IBGE. (2016). Sintese de indicadores sociais: Uma análise das condições de vida da população brasileira: 2016/IBGE, coordenação de população e indicadores sociais. Rio de Janeiro: IBGE. p. 146.

Larivière, B., Bowen, D., Andreassen, T. W., Kunz, W., Sirianni, N. J., Voss, C., . . De Keyser, A. (2017). Service encounter 2.0: An investigation into the roles of technology, employees and customers. Journal of Business Research, 79. http://dx.doi.org/10.1016/j.jbusres.2017.03.008

Lyons, S. T. and Kuron, L. K. J. (2014). Generational differences in the workplace: A review of the evidence and directions for future research. Journal of Organizational Behavior, 35(S1), 39-S157. https://doi.org/10.1002/job.1913

Lyons, S. T., Urick, M., Kuron, L. and Schweitzer, L. (2015), “Generational differences in the workplace: there is complexity beyond the stereotypes”, Industrial and Organizational Psychology, Vol. 8, pp. 346-356, doi: https://doi.org/10.1017/iop.2015.48

Nomura, T., Kanda, T., Yamana, S. and Suzuki. T. (2011), "Exploring influences of robot anxiety into HR", Proceedings of the 6th international conference on Human-robot interaction, doi: https://doi. org/10.1145/1957656.1957737

Novella, R., Repetto, A., Rabino, C. and Rucci, G. (2018). Millennials na América Latina e no Caribe. Trabalhar ou Estudar? Sumário Executivo, Washington, DC: BID-Banco interamericano de desarrollo. Retrieved from www.iadb.org/es/millennials/home (Acesso em 09/05/2019)

Pinkwart, N. (2016). Another 25 years of AIED? Challenges and opportunities for intelligent educational technologies of the future. International Journal of Artificial Intelligence in Education, 26(2), 771-783. doi: https://doi.org/10.1007/s40593-016-0099-7

Schein, E. H. (1985). Career anchors: Discovering your real values, London, United Kingdom: Pfeiffer and Co.

Schein, E. H. (1990). Career anchors: Discovering your real values, San Diego, CA: Pfeifer and Company, University Associates, Inc.

Schein, E. H. (1996a). Identidade profissional: Como ajustar suas inclinações a suas opções de trabalho, São Paulo, Brazil: Nobel. 
INMR

17,4

Schein, E. H. (1996b). Career anchors revisited: Implications for career development in the 21st century. Academy of Management Perspectives, 10(4), 80-99. doi: https://doi.org/10.5465/ame.1996.3145321

Silva, R. C., Trevisan, L. N., Veloso, E. F. R. and Dutra, J. S. (2016). Âncoras e valores sob diferentes perspectivas da gestão de carreira. Revista Brasileira de Gestão de Negócios, 18(59), 145-162. https://doi.org/10.7819/rbgn.v18i59.2260

Sutton, S. G., Holt, M. and Arnold, V. (2016). The reports of my death are greatly exaggerated' Artificial intelligence research in accounting. International Journal of Accounting Information Systems, 22, 60-73. doi: https://doi.org/10.1016/j.accinf.2016.07.005.

Trevisan, L. N., Veloso, E. F. R., Silva, R. C. and Dutra, J. S. (2016). Âncoras de carreira e tecnologia na percepção sobre estresse no ambiente de trabalho. Revista Organizações em Contexto, 12(24), 65-90. https://doi.org/10.15603/1982-8756/roc.

Urick, M. J., Hollensbe, E. C. and Fairhurst, G. T. (2017). Differences in understanding generation in the workforce. Journal of Intergenerational Relationships, 15(3), 221-240. https://doi.org/10.1080/ 15350770.2017.1329583

Veloso, E. F. R., Dutra, J. S. and Nakata, L. E. (2016). Percepção sobre carreiras inteligentes: as diferenças entre as gerações Y, X e baby boomers. Rege - Revista de Gestão, 23(2), 88-98. https:// doi.org/10.1016/j.rege.2015.05.001

Veloso, E. F. R., Silva, R. C., Gomes, D. F. N., Trevisan, L. N. and Dutra, J. S. (2014). Momento social, valores e expectativas: Como as mudanças econômicas influenciam a visão dos jovens sobre o trabalho?. Revista Organizações em Contexto, 10(19), 279-305. doi: https://doi.org/10.15603/19828756/roc.v10n19p279-305

Veloso, E. F. R., Silva, R. C. and Dutra, J. S. (2012). Diferentes gerações e percepções sobre carreiras inteligentes e crescimento profissional nas organizações. Revista Brasileira de Orientação Profissional, 13(2), 197-208.

Veloso, E. F. R., Trevisan, L. N., Silva, R. C. and Dutra, J. S. (2018). The use of traditional and nontraditional career theories to understand the young's relationship with new technologies. Revista de Gestão, 25(4), 340-357. https://doi.org/10.1108/REGE-12-2017-0008

\begin{abstract}
About the authors
Joel Dutra Dutra is a Phd and a Professor in administration at the University of São Paulo (FEAUSP), where he is responsible for the research group on leadership and succession process. He is also one of the coordinators of the People Management Studies Program (PROGEP) at the FIA Faculty of Business and Administration.

Leonardo Trevisan is a Professor at the Pontifical Catholic University (PUC-SP), where he is editor of the review (RECAPE (Review of Careers and People) and responsible for the research group in career studies. He is also a Professor at the Escola Superior de Propaganda e Marketing (ESPM). Doctorate in Political Science at the University of São Paulo and Postdoctoral in Economics at the University of London.

Elza Veloso is a Phd in administration at the University of São Paulo (FEA-USP). She is currently Executive Coordinator and Professor of the professional master's degree at the FIA Faculty of Business and Administration. She is also a professor at Mackenzie Presbyterian University.

Rodrigo Cunha da Silva is currently a professor in the professional master's degree at Anhembi Morumbi University and at FIA Faculty of Business and Administration. PhD in Administration from the University of São Paulo. Rodrigo Cunha da Silva is the corresponding author and can be contacted at:rdgcdasilva@gmail.com
\end{abstract}

For instructions on how to order reprints of this article, please visit our website:

www.emeraldgrouppublishing.com/licensing/reprints.htm

Or contact us for further details: permissions@emeraldinsight.com 